\title{
Real, Meaningful Mathematics
}

\section{A Review of All Positive Action Starts with Criticism, Hans \\ Freudenthal and the Didactics of Mathematics. \\ Sacha La Bastide-van Gemert (2015). Dordrecht, Netherlands: Springer Science+Business Media.}

\author{
Koeno Gravemeijer ${ }^{1}$
}

Published online: 18 March 2016

(C) Springer International Publishing Switzerland 2016

Hans Freudenthal has a worldwide reputation as visionary scholar. In the Netherlands, he has become an almost mythical figure: he prevented New Math from getting a foothold in our country, and was the founding father of what has become the domainspecific theory of realistic mathematics education (RME). This theory, which was developed in the IOWO (the current Freudenthal Institute), gained international recognition, and has been adopted by Dutch primary and secondary schools. This mythical status was fueled by Freudenthal's standing as mathematician, his professorial appearance, and, not least, his fierce criticism. This is reflected in La Bastide-van Gemert's choice of the quote, "All positive action starts with criticism", as the title of her biographical study.

Another factor that contributed to Freudenthal's mythical status was that he liked to portray himself as "a Don Quixote-like person (...), a lonely fighter against the evil tendencies in mathematics education (...) an 'enfant terible', proud of his 'mischiefs', always rowing upstream, but eventually being right," as La Bastide-van Gemert (2015, 4) puts it. Apparently she was intrigued by this image; the main objective of her book is to find out in how far this image corresponds with reality. Actually she does much more: she conscientiously describes his life, his work, and the way his thinking developed. As a basis for this, she mainly relies of Freudenthal's personal archive, which encompasses his publications, his correspondence, and unpublished material.

Koeno Gravemeijer

koeno@gravemeijer.nl

1 Eindhoven School of Education, Eindhoven University of Technology, Rijnsburgerweg 47, 2334BG Leiden, The Netherlands 
She not only analyzes and summarizes numerous texts that would otherwise be inaccessible, she also illuminates his work with a wealth of citations. This offers a unique insight in Freudenthal's ideas and actions at that time. One important source is Freudenthal's autobiography, titled, "Schrijf dat op Hans" ("Write that down, Hans"), which allows her to include Freudenthal's personal perspective. She notes that her study is neither a didactical study nor a biography. It is an historical analysis aiming to construct an image of Freudenthal and his work. She limits herself to what she sees as the "construction phase" of his didactical ideas, which in her view ends around the 1970s. Another limitation appears to be that - in part because of the chosen periodthe main focus is on Freudenthal's role in the Netherlands.

The book is structured more or less chronologically. La Bastide-van Gemert reports that Freudenthal was born in Germany, studied mathematics in Berlin, and migrated to Amsterdam on request of L.E.J. Brouwer. She then delineates the 2nd World War period, when Freudenthal — being Jewish—was suspended from the University and filled his time with studying the literature on mathematics education. Next she describes how he became active in mathematics education communities and started writing for the general public. She gives special attention to his relationship with the Van Hieles, and to New Math. When arriving at the 1970s she takes stock of his work and his thinking. In the epilogue she addresses the critique that has been voiced against RME. Complaints about mathematics education in the Netherlands started to come up in the first decade of this century, and were quickly picked up by the media. The main complaint was, and still is: Students leaving secondary education have not learned the standard algorithms, and do not master the basics; RME centers too much on story problems and circuitous solution methods at the expense of training in routine procedures.

In a short review it is impossible to do justice to such a rich and comprehensive book (of 386 pages). I will therefore focus on two defining episodes - the war period and his work with the Van Hieles - though not without the nagging feeling that I am omitting important themes. But let me first discuss the answer to the question about "the myth". According to La Bastide-van Gemert the answer is not unambiguous. She observes that Freudenthal was surely not a lone fighter but an active participant in the mathematics education community at the time New Math became an issue. His position towards New Math seems less clear. On the one hand this has to do with his strategy to "cooperate in order to adjust". On the other hand it has to do with his priorities. He strongly believed in mathematical thinking as the main goal of mathematics education. In line with this emphasis on mathematical thinking he took the view that the way in which mathematics is taught is more important than what mathematical content is taught. La Bastide-van Gemert suggests that this is the reason why he was rather ambivalent towards New Math. He was not really concerned about the New Math content, but he balked at it every time he saw how this content was worked out in curricula. Another factor, in her view, was that Freudenthal had great confidence in teacher professionalization. For a long time he entertained the rather naïve idea that if teachers were enabled to analyze the content from a higher mathematical stance, they would be able to teach it in a sensible manner. Eventually, however, he would be seriously disappointed in this respect. Consequently his conditional and often implicit acceptance of the New Math disappeared and turned into a powerful rejection, and he developed into one of its fiercest opponents. 


\section{"Rekendidactiek"}

In retrospect, wartime appears to have been a decisive period for Freudenthal's development as a mathematics educator. La Bastide-van Gemert describes how he filled his time while being suspended from university. He regularly helped his elder sons with arithmetic, which aroused his interest in the didactics of arithmetic. As a result of this, he started an extensive study of the available literature. Through his wife, he had access to all libraries in the Netherlands. She shared this interest in education - she later introduced Jenaplan Education in the Netherlands. Freudenthal studied 370 titles, and made numerous notes, which laid the basis for a book entitled "Rekendidactiek" (Didactics of arithmetic). However, in the end only the first part of the intended book was actually written. This part mainly consists of a study of all sorts of auxiliary sciences, which he eventually rejected for various reasons. Although he apparently did value the American literature on theoretical and practical pedagogy, this does not come to the fore in this first part.

The work Freudenthal did in preparing the book gave him a head start after the war. La Bastide-van Gemert recounts that, in the summer of 1945, he held a lecture titled, "Education for Thinking", at a conference of the Working Community for Education and Instruction (WVO). As the title of his lecture suggests, Freudenthal emphazised the importance of teaching students to think. He did not, however, subscribe to the then popular ideas about the formative value of mathematics education. Instead he advocated for content-specific ways of thinking, primarily mathematical thinking. He argued that everybody should learn to think, but for some mathematical thinking would be too ambitious. Note that he changed his view later: when the expanded role of mathematics in our society convinced him that everybody needed mathematics, he became a protagonist of "Mathematics for All".

According to La Bastide-van Gemert, Freudenthal further argued that solving word problems could foster arithmetical thinking. He acknowledged that by working on relatively simple word problems students might develop routine ways of responding. But when the problems become more difficult and less illustrative, students can no longer rely on rote response and then "thinking is the only remedy". He did not see a role for algorithms in this respect; those might as well be acquired by rote learning. He reasoned that one should look for stories taken from real life that would appeal to selfmotivation. La Bastide-van Gemert further notes that he aligned himself with John Dewey, although he considered Dewey's actual tasks too artificial and too far removed from reality.

\section{The Van Hieles}

La Bastide-van Gemert illuminates the fact that the work of the van Hieles proved crucial in the development of Freudenthal's thinking. In the 1940s and 1950s he already had clearly in mind how things should not go in mathematics education: the logical order of mathematics should not be decisive for the psychological and educational order. Instead, one should attune the mathematics to the level of the students. But he could not yet come to grips with how that could be done. 
"The answer - a theoretical answer-followed when the Van Hieles were working on their theses, so about 1955/56: the levels of the Van Hieles [...] what I learned from the Van Hieles I processed in my own way- that is the way it goes." Freudenthal, 1987, cited by La Bastide-van Gemert [p. 190]

La Bastide-van Gemert explains that Van Hiele (1973) observed that teachers and students had different frameworks of reference and, as a consequence, often used the same words with different meanings. He illustrated this with the word 'rhombus'. A rhombus signifies a figural shape for younger secondary school students. For the teacher, however, the word rhombus signifies a set of geometrical relations: the sides are pairwise parallel, all sides have equal lengths, the diagonals intersect orthogonally; the facing angles are equal. On the basis of this network of geometrical relations the teacher can reason that, when all sides of a quadrilateral have equal lengths, the diagonals will intersect orthogonally, etc. For the students, however, such a line of reasoning is out of reach. In relation to this, Van Hiele speaks of different levels of thinking, and La Bastide-van Gemert describes four levels. In the brief exposition below, however, I will use the grouping in the three levels Van Hiele (1973) originally discerned, and which are also used by Treffers (1987) in his exposition on RME theory. At the so-called zeroth level, the student works with geometric figures as concrete objects and images. In doing so the student discovers properties and relations. The student forms a network of relations, and the words rhombus, side, angle, and square become junctions in this network of relations, at which point the student has reached the first level. Subsequently the student can form a new network, which concerns logical ordering, proving and such, and can be characterized as organizing relations between relations.

La Bastide-van Gemert argues that what made Van Hiele's theory so important for Freudenthal was that it offered a theory about how students could construct more sophisticated mathematics, namely by constructing networks of mathematical relations. She describes this as an abstraction from Van Hiele's theory, because it transcends the connection with geometry. This idea, however, was not new; she herself notes that the Van Hieles already pointed to the possibility of applying the theory to other subjects in 1957. What Freudenthal did do is elaborate on the underlying principle:

"At every level the subject matter is a certain field that will be organized on this level. The devices of organizing on a certain level will form the field and therefore the subject matter, on the consequent higher level." (Freudenthal, 1957, Cited by La Bastide-van Gemert, p. 192)

According to La Bastide-van Gemert, this harks back to earlier ideas, when Freudenthal already spoke of re-examining the old solutions at each new stage, a principle, he later described as 'reflection as a level-enhancing means'. By that time Freudenthal had exchanged the strict tri-partition for loose progression of micro-levels.

La Bastide-van Gemert further elucidates how Freudenthal developed the notions of "anti-didactical inversion" and "guided reinvention" around the early 1960s. Writing 
about trends in modern mathematics he noted that the modern mathematical systems came about by organizing mathematical subject matter. This may have triggered the idea of the anti-didactical inversion as characteristic in traditional mathematics education that starts with definitions, for this is completely contrary to what creative mathematicians do. Implicit in this line of reasoning is the notion of mathematics as a human activity, which Freudenthal would later coin as the mantra on which RME is based. He underpinned the idea of guided reinvention with a reference to the way adult mathematicians work, arguing that the easiest way to understand a mathematical paper is to reinvent its results. Based on this observation, he reasoned that reinvention should play a more universal part in the learning process in guided form, while cautiously adding, as La Bastide-van Gemert puts it, that this idea still had to prove its value in practice.

In retrospect, it may be noted that guided reinvention brought algorithms back into the picture. Work at the IOWO showed that teaching algorithms could be combined with fostering mathematical thinking by designing instructional sequences in which the algorithms were invented. This corresponded with Freudenthal's idea that mathematical activity was more important than mathematics as a product. On this point he would argue that the activity of algorithmetizing was more important than learning the algorithms, a view that fits well with the current ideas on the importance of 'computational thinking' (e.g., Wing 2006).

\section{Conclusion}

At the end of her book, La Bastide-van Gemert addresses the current critique of RME in the Netherlands. It seems as if we are back where Freudenthal started, with the same discussion. She rightly remarks that the critics fail to make a distinction between the actual educational practice and the theory of realistic mathematics education. In this respect too her book is illuminating. It contrasts sharply with the simplified version of RME critics react against. What emanates from this book is Freudenthal's concern about teaching real, meaningful, mathematics. This comes to the fore in the case he makes for mathematical thinking, in his mantra of mathematics as a human activity, his identification of the anti-didactical inversion, and his analysis of what makes mathematics useful.

When preparing this book review constantly topics came to my mind that I knew I should include, but could not. This only underscores the wealth of information this book has to offer about Freudenthal and his work.

\section{Note}

Pierre van Hiele is well-known for his theory of levels. It is less well known that he worked closely with his wife Dina van Hiele-Geldof, who was also a mathematics teacher and was awarded her doctorate on the same day as her husband. La Bastide-van Gemert explains that Dina focused on an analysis of the practice of 
initial geometry education, while Pierre was more involved with the theoretical side. This review uses Van Hiele, singular, to refer to Pierre van Hiele.

\section{References}

La Bastide-van Gemert, S. (2015). All positive action starts with criticism, Hans Freudenthal and the Didactics of Mathematics. Dordrecht, Netherlands: Springer Science+Business Media.

Treffers, A. (1987). Three dimensions (Vol. 3) (Vol. 3). Dordrecht: Reidel Publishing CompaSpringer Science \& Business Media.

Van Hiele, P. M. (1973). Begrip en inzicht. Purmerend: Muusses.

Wing, J. M. (2006). Computational thinking. Communications of the ACM, 49(3), 33-35. 